\title{
Defence heritage moves on to civilian futures
}

\author{
C. Clark \\ The Wessex Institute of Technology, UK
}

\begin{abstract}
Significant historic sites associated with national defence are on the closure list in many countries, as armed forces are reduced and regrouped. This paper draws on recent experience of their conversion to civilian uses in the US and Europe.

Government and independent research devoted to this specialised area has appeared in England, France, Germany and the US, although the topic is still rarely explored. In the 1990s, English Heritage produced thematic studies of dockyards, barracks and subsequently airfields to identify important examples of building types worthy of preservation. The UK Ministry of Defence produces annual Stewardship reports on the defence estate. In 2002 the French Ministry of Defence celebrated its heritage in a lavishly illustrated book: Patrimoine militaire (Editions Scala, Paris). The Bonn International Center for Conversion (BICC) does pioneering work on decontamination and the economic effects of closure upon defence dominated communities. In the 1988-1995 rounds of the US Base Realignment and Closure process used by the Department of Defense were used to review and restructure its military installations, and the US House Armed Services Subcommittee on Readiness have held hearings on the management of historic military properties and installations.

Countries differ considerably in the regulations which govern the transitional process to new uses. How defence sites are disposed of - by free transfer, development by the local authority, public private partnership, or sale to the highest bidder - has a strong influence on the power of different parties to influence decision-making and hence on the outcomes and new land uses.

This rapidly moving and widespread process is still not much studied. There is little interchange between countries undergoing similar experiences, the importance of historic defence sites to their local communities is both cultural and social. More needs to be done to share good practice in this most important of transitions.
\end{abstract}




\section{What is being disposed of?}

Significant historic sites associated with national defence are on the closure list in many countries, as armed forces are reduced and regrouped. In the 1988-1995 rounds of the US Base Realignment and Closure process used by the Department of Defense to review and restructure its military installations, 97 major bases were closed, and there are plans to close 25 more and 'reconfigure' 26 others in the current round. Included are National Historic Landmarks: Fort Monroe in Virginia, Fort McPherson in Georgia, Vancouver Barracks in Washington and Fort Haye in Ohio. In the UK Hounslow Barracks, Haslar Hospital and HMS Daedalus are amongst the historic properties to be sold, but also for sale are firing ranges - brownfield sites par excellence [1].

\section{Research into the history, condition and future of defence sites}

Understanding the history of defence heritage sites and maintaining them in good condition are essential first steps in their move towards civilian futures. Research in England identifies and celebrates the range of defence structures identified as heritage. The British Ministry of Defence is responsible for the largest number of historic environment assets on the UK government estate, with approximately 650 listed buildings and over 1,000 scheduled monuments [2]. In 1998 English Heritage produced thematic studies of dockyards and barracks to identify important examples of building types worthy of preservation [3]. In 2004-5 they conducted a study of the development of military aviation from its inception and up to 1945 . The aim was to ensure that airfield sites are adequately recorded and protected, and to document their historical context for management and educational purposes. This study culminated in December 2005 , with the listing of 255 buildings, 86 of which are on the defence estate on 19 MOD sites. The extensive restoration of the UK Ministry of Defence (MOD) Main Building in Whitehall London, constructed over the period 1938 to 1959 [4] is featured in the Department of Culture, Media and Sport's forthcoming Biennial Report. However, the Stewardship Report on the Defence Estate 2005 refers in its section: 'Taking account of the wider interests of society with particular reference to sustainability and the environment'- to defence historic buildings at risk The MOD has committed itself to reducing their number. In 2001 there were 43 at risk: $6.1 \%$ of the total; this has now been reduced to 32 . However, $33 \%$ of the 9000 Scheduled Ancient Monuments on MOD land were in fair condition, while $21 \%$ in poor or unknown condition [2]. MOD advisors on the Historic Environment have expertise in both historic buildings and archaeology.

A major enhancement in civilian input into UK planning of the future of defence sites is likely to follow abolition of the Crown Exemption, which exempts government departments from civil planning law. In 2005 the Office of the Deputy Prime Minister drew up the timetable for its removal under the 2004 Planning and Compulsory Purchase Act in 2006. But whilst this removal applies 
to town and country planning and listed buildings, it does not apply to scheduled monuments, which is an omission of the 1979 Ancient Monuments and Archaeological Areas Act. However, this will be rectified as part of the DCMS Designation Review which is streamlining the designation system, but in England only. Scotland and Wales have separate heritage organisations [5]

In March 2006 the US House Armed Services Subcommittee on Readiness held a hearing on Historic Military Properties and Installations to hear testimony on the management of historic military properties and installations by the Armed Services. Phil Grone, the deputy undersecretary of defense for the environment and installations outlined the Department of Defense's (DoD) program to manage historic properties. DoD has management responsibility for 75 National Historic Landmarks - as well as nearly 600 historic entries listed on the National Register of Historic Places - which encompass more than 19,000 individual historic properties located on over 200 military installations. The DoD has a broad strategic framework for managing the agency's historic properties that includes early planning and the use of Integrated Cultural Resource Management Plans (ICRMP) which not only identify the inventory of assets (historic buildings and structures, traditional cultural places, archeological sites), but also include the actions needed to manage and maintain those assets. Interestingly, in view of the common prejudice that older properties cost more to maintain than modern buildings, Grone also noted that DoD studies have reinforced the conclusion that "on a per square foot basis, the costs of maintaining Historic Properties are frequently comparable to the costs of maintaining non-Historic Properties." He cited GSA statistics which "found that operating costs for the historic buildings in the study averaged 10 percent less per rentable square foot than non-historic properties, with utility costs 27 percent less", due to superior construction [6].

The Bonn International Center for Conversion (BICC) does pioneering work on decontamination and the economic effects of closure upon defence dominated communities in many countries including Germany. As the bibliography in my study of European dockyards demonstrates [7], however, literature on postdefence reconstruction, its economic, social, spatial and physical impacts, and the implications for the historic defence estate is rare, though more common in the US. Rachel Woodward in Military Base Conversion and Rural Development [8] says that while the effect of conversion on the defence industry has dominated conversion research, military base conversion is the Cinderella of conversion studies. An example is Restructuring The Global Military Sector Volume II: The End of Military Fordism [9] which is mainly focussed on defence conversion, although there are regional studies on Ukraine and the Philippines. Because of the visibility of defence industrial restructuring in economic and policy terms, and the position of the defence industry as connector between security and the economy [10], the conversion of military properties and lands such as airfields, depots, barracks, dockyards, training centres has received far less attention. As Broska [11] notes, this absence in social scientific research has left significant gaps in our knowledge about the effects of base closures and the prospects for civilian reuse in many parts of the world. Britain is a case in point. There are two reasons for this lack of critical appraisal. Although base 
conversion may be intermittently highly visible in land use and development policy debates, for example, following publication of the UK Strategic Defence Review [12] and the Comprehensive Spending Review [13] administrative and academic interest is not sustained because of the long timescales involved [14]. In contrast is the sustained work of the Bonn International Center for Conversion, which since 1994 has been actively tracking all aspects of the conversion processes in central and eastern European countries; for example military expenditure, surplus weapons, demobilisation, conversion of military research and development, conversion of defence industry and base conversion. It "facilitates the processes whereby people, skills, technology and economic resources are shifted away from the defense sector and applied to alternative civilian uses" [15]. Their publications include their Conversion Surveys of Global Disarmament, Demilitarization and Demobilization of 1996, 1997, 2002 and 2003 [16], papers on Base Closures in Hungary and Poland, and an extensive study commissioned by the German Federal Ministry of Environment [17]. Henri Myrttinen's study of central and eastern Europe [18] and the BICC Brief 18 on Conversion in South Africa in the 1990s [19] offer detailed analysis of experience.

\section{The effects of disposal systems on outcomes}

Countries differ considerably in the regulations which govern the transitional process to new uses, with consequent effects on decision-making and on the social, environmental and economic outcomes. The emphasis in the United Kingdom is on achieving a high financial return to the Treasury, a stipulation which has considerable effects on the subsequent land uses. The Ministry of Defence estates agency has a requirement by the Treasury to achieve maximum financial receipts from disposal of defence property. For the current year this is $£ 151$ million [5].

High end housing and leisure shopping bring developers who have paid a high price the highest return. The sale price may be slightly reduced for historic sites according to guidelines for government departments by the Department of Culture, Media and Sport. In contrast, the US Department of Defence (DOD) has a federal preservation officer whose task is to convey to local communities whose economy may be blighted by defence cuts how historic properties can be an engine for redevelopment. Objective reviews of each sites and public hearings were held before the 2005 recommendations on closures were made to the President. The DOD Office of Economic Adjustment helps local communities plan new uses for surplus properties.

\section{Public/private partnerships}

In Britain, where there is a government target for $60 \%$ reuse of brown land, a new development is the reliance on public/private partnerships to bring unused historic defence areas back into use. Perhaps the MOD's desire to retain receipts from property disposals rather than see them revert to the Treasury underlay the 
new strategy for Portsmouth dockyard in southern England. Portsmouth Naval Base is still the berthing port for many naval sips: carriers, Type 23 frigates, Type 42 destroyers, mine counter measure vessels and patrol ships, with facilities to berth visiting international ships. In view of a continuing need for defence spending, Project Prime (Portsmouth Regeneration in the Maritime Estate) was launched in 2004/5 after three years' gestation. It represented a new model of naval base renewal for the British Ministry of Defence. Although it was cancelled in July 2005, it is described in detail here because it illustrates the complexity and sheer difficulty of achieving sustainable naval waterfront renewal, especially when the navy is still operational next door. Project Prime's aim was:

"to generate income [from the private sector] to invest in a stream-lined Modern Naval base, directing resources in support of the [national defence] front line, by the creation of residential, leisure and commercial opportunities, providing employment opportunities within the local area, and preserving and enhancing buildings of National Historic Importance" (my insertions) [20]

In October 2001 Defence Estates, the MOD's property agency, was commissioned to deliver a master plan for the naval base. This document identified an area of approximately 30 acres in the south west corner of the base capable of release for commercial exploitation, whilst maintaining the operational effectiveness of the dockyard of 333 acres. This estate lies within a conservation area containing listed buildings, ancient monuments and other historic structures. A small area of what was under consideration has been leased for 99 years since 1985 to the Portsmouth Naval Base Property Trust, but the dowry which accompanied the setting up of the Trust was nowhere near enough to bring all the old buildings back into repair or to fully convert them to new uses. Some of the empty space in the masthouse, stores-houses and boathouses has gradually been refurbished and reused for the Royal Naval Museum, the Mary Rose Trust, dockyard trades display and the interactive Action Stations visitor attraction, as well as a café and art gallery, but fundraising for each project was time consuming and expensive, and upper floors remain unused.

The aim of Project Prime for the MOD was to use capital raised through the release of a larger area to civilian capital investment to re-invest the proceeds in the MOD estate, re-providing facilities lost within the hived off area with modern equivalents in the naval enclave. It would also have relieved the Naval Base Commander's budget of the high maintenance cost associated with the historic estate [21]. It was hoped 'to save upwards of $£ 25$ million. Naval Base Commander Cdre. Amjad Hussain said that 'buildings such as the Old Naval Academy, Anchor and Stony Lanes, Short Row and the Block Mills had served the Navy well, but no longer met the needs of the $21^{\text {st }}$ Century fleet' [22]. Funds from Project Prime would not have disappeared into the 'black hole' of the Treasury, but have been reinvested in modern facilities such as offices in other areas of the naval base [23] and restoration of the internationally important Block Mills, currently at the top of English Heritage Buildings at Risk list. 
A single Public/Private Partner was being sought to provide a "holistic" solution for the entire Project PRIME development area by an integrated project team from Defence Estates, the Naval Base Commander organisation, supported by Partnership UK, who are co-sponsoring this project. Partnership UK is a Public/Private Partnership stemming from the HM Treasury Private Finance Initiative Taskforce that develops the private finance agenda and 'Wider Markets' initiatives on behalf of government - to achieve enhanced value by going to the market [21].

The assets of the Property Trust and the MOD would have been taken on by a PPP (49\% Public/51\% Private Partnership) to provide new facilities for the naval base and open up 60 listed buildings into the public area, offering them to a developer. Most are Grade II, but Block Mills is a Scheduled Ancient Monument and Grade I, and, shockingly, as already said, it is also No. I building of the English Heritage list of MOD Buildings at Risk. Very large financial resources are needed for restoration and repair, and for conversion to new uses. Instead of the tight security of a naval base, there would have been open access to the public - to buildings locked away for 300 years. The intention was to appoint one developer to take on all the buildings - the majority of which will be profitable conversions to residential use - for example the Naval Academy and Ropery - which might provide cross subsidy for others, such as Block Mills.

Civilian expertise was crucial. The MOD had advice on planning, as well as drawing on commercial and technical advice on the economics and viability of Project Prime from King Sturge (commercial agents) and ENTEC (multidisciplinary practice), The project was led by Defence Estates, English Heritage, the Naval Base Property Trust and Portsmouth City Council planning, economic development, engineering and conservation officers [23]. There are currently 500,000 tourist visits each year and 375,000 people paying to visit the preserved ships, museums and Action Stations, but the Trust would like to move away from reliance on tourism into a more diversified economy, open in the evenings instead of the site being closed in at night within naval security.

The MOD also draws advice from Defence Estates' Sustainability and Conservation group based in Warminster, which is responsible for conservation of buildings, wildlife, sustainability, energy efficiency, and green eco-building regulations. Up until recently the MOD's tactic was to sell redundant property, but according to Defence Estates, this doesn't necessarily bring in the best return. Although the MOD had not done so before, Public/Private Partnerships have been used by other government departments: for example British Waterways' Isis project, where the whole of the waterside estate including lock keeper's cottages and land was leased away to a developer. Another example is One North East where Newcastle City Council and Gateshead have passed over their properties [21]. Project Prime and Defence Estates MODE London, which used a similar scheme to reduce MOD's footprint in London from 13 sites to three or four, were intended as showcase projects for this type of procedure for the MOD. If it had been successful, the Project Prime model would have been rolled out elsewhere as a mechanism for other surplus MOD land. 
The Project Prime developer was to have been engaged on a contractual basis. The MOD would have retained the freehold; the Property Trust would have surrendered its current lease of the Heritage Area and taken on a 125 year lease for the larger Project Prime area, carrying on with its guardianship of the site. It would have been responsible for ongoing repairs and maintenance of buildings and continue its role as their interpreter for the benefit of the public. The developer would have been granted a lease of one day less than 125 years, and paid ground rent to the Trust; they would then have realised (or 'stripped out') the value of the converted buildings. Owners of residential development would have had long leases, which might have been reviewed in the light of new legislation on tenants' right to buy under the new title of commonhold, which brings the UK into line with Europe, Canada, Australia and the US [24]. In view of the several layers of heritage protection on existing structures and lack of cleared land, there would have been only limited facilities for rebuilding and new construction. In March 2005 a design brief - or Memorandum of Information was discussed with developers [25]. 67 companies expressed interest in response to the announcement in the EU official journal in September 2004: contracts have to be open to all member states. All the companies were British. Berkeley Homes, which had redeveloped Gunwharf Portsmouth, Royal Clarence Yard Gosport, Woolwich Arsenal and other military sites, and Crest Nicholson who had permission for a very large housing scheme on the adjoining Heritage Car Park were not in the final six. Vosper Thorneycroft Shipbuilding who built and operate the vast ship assembly plant built inside the dockyard which had transferred from Woolston Southampton was part of a consortium, reflecting the huge scale of the project. The front runners were utility company Amec, and housebuilders Persimmon who were also in a consortium. The Naval Base Property Trust was part of the two-week sifting process. The developers were shortlisted via a questionnaire and evaluation in a formal procurement process on their experience, track record, historic conversion, MOD contracts, health and safety, sustainability and long term issues, awarding a graded score [23]. The next stage was to invite the six to submit further details to the Industry Day in June, but the project was cancelled in July 2005. Details of potential uses and their physical implications for the historic buildings are discussed in the chapter on heritage.

It was true to say that Project Prime did not enjoy unmixed support; senior naval officers who dominate the Navy Board and deplored recent defence cuts would have lost their valued social facilities at the Naval Academy; and Admiralty House, which is occupied by the Second Sea Lord. Both were included in the area on offer. In July 2005 after the two suicide bombers' attacks on London and changes at the top of the navy, as already said, the $£ 50$ million project was cancelled. The Navy Board concluded it was too risky to go ahead with large scale development by Project Prime, considering that Portsmouth was likely to be the place where the new breed of supercarriers were to be berthed. The proposal to put hundreds of flats and offices near the planned berths was deemed too much of a security risk. "We have two conflicting plans...There's no choice between the two because the first [the berth] is important for the future 
of the navy and the development of this region's economy as a whole" [26]. As there are existing tall blocks of flats nearby and a very large new complex was granted permission just over the dockyard wall at the same time, as well as the new flats arising on the Gosport shore across the harbour, this statement seems a touch disingenuous.

Another factor was that Project Prime stacked the upfront costs enormously high onto the private developer. The Ministry of Defence wanted all their new offices to be constructed up front, to condense the operational area within more secure and easily defensible boundaries - before the development started and there was any financial return from residential redevelopment of the historic buildings, the likely highest earner. This put developers off - they would have had to take too high a risk. The Naval Base Property Trust advised Defence Estates that Project Prime would have a struggle to be viable because the MOD wanted so much office accommodation before the developers got their money back. There might be an ultimate end profit, but return on capital employed would have been deferred too long [23].

Since the cancellation of Prime, the boundaries of the residential area have been redrawn $300 \mathrm{~m}$ from the jetties. Defence Estates considered how to use the historic buildings on a one by one basis. To do nothing is not an option, because the historic buildings are unusable in their present state. Instead of a big bang, there's a return to an evolutionary process. After the cancellation, Option 1 was to identify other defence departments wishing to occupy the buildings to be released, but they don't lend themselves to use, for example as offices. Option 2 was to apply to the Chief of Fleet Support - to ask that since buildings occupied by residents in such close proximity to ships raised security issues, what uses are acceptable: offices, bars, restaurants, storage, friendly MOD tenants, Vospers, Fleet Support Limited, a school? Security is changing all the time; the naval base cannot be freed from perceived threat.

A critical problem is that sustaining the complex infrastructure of historic naval sites for civilian futures requires careful long term provision once this is no longer the responsibility of the defence budget. Maintenance of dock walls, culverts, basins, caissons, cranes and other infrastructure would have been separately funded, via a sinking fund which service charges to the new occupiers would not cover. A precedent for this is the Chatham Maritime Trust which was established to look after and collect charges for maintenance - on the advice of Price Waterhouse who analysed commuted maintenance charges which were not included in service charges. This advice was commissioned by the South East England Development Agency and English Partnerships which took on part of Chatham dockyard [23].

But despite the cancellation of Project Prime, change to a new, mixed government/civilian future has already taken place in Portsmouth dockyard, which was ground-breaking in itself. Large areas had already been leased to defence contractors VT Shipbuilding and BAE who jointly own Fleet Support Limited. These might be regarded as friendly users, but they work on civilian as well as naval contracts to ensure continuity of work. VT built a huge new ship 
assembly shed over No. 13 Dock and BAE converted two floors of the listed Iron and Brass foundry.

Other public/private partnerships may not result in maritime reuse: in Karljohansvern in Norway where there are about 90 buildings older than 1940 considered as historic buildings, most of the buildings directly connected to shipbuilding are in private use, such as smaller houses used as offices and residences. A private company used the dock and several buildings from the late 1960 s to the 1990s. Parts of the fortifications were destroyed when the shipyard extended its activity early in the 1970s [27].

\section{Conclusion}

The lesson from Portsmouth and from other examples such as Charlestown Boston is that the private sector cannot do everything. Some public investment is required for the start-up phase until other sources of income emerge. If the public sector cannot justify its grants for waterfront redevelopment projects as profitable real-estate ventures, then political and urban design criteria should also be included in their assessment [28].

This rapidly moving and widespread process is still under-researched, and there is little interchange between countries undergoing similar experiences, except within Europe, where the EU has financed exchanges between affected local governments. Military geographies are everywhere; every corner of every place in every land in every part of the world of ours is touched, shaped, viewed and represented in some way by military forces and military activities [29]. When the military leave, the importance of historic defence sites to localities is cultural and social as well as economic. More needs to be done to share good practice in this most important of transitions for former defence heritage sites.

\section{References}

[1] Wintour Patrick and Elliott Larry 2006 'Brown taunts the Tories: we invest, you cut taxes Education and environment made priorities but no more for health' the Guardian 23 March 2006 page I

[2] Ministry of Defence 2006 The Stewardship Report on the Defence Estate Ministry of Defence London

[3] English Heritage 1998 Barracks Thematic List Review Summary Report and Recommendations English Heritage London English Heritage 1988 Royal Naval Dockyards Thematic List Review Summary Report and Recommendations English Heritage London

[4] CTS Media Bath n.d. Your Guide to Main Building

[5] Hills-Spedding Guy 2005 Defence Estates Email on Crown Exemption to Celia Clark

[6] National Trust [US] Public Policy Weekly Bulletin March 10, 2006, Volume 1, Issue No. 4 
[7] Clark Celia 2000 Vintage Ports or Deserted Dockyards; differing futures for naval heritage across Europe The University of the West of England Working Paper No. 57 July 2000 Bristol

[8] Woodward Rachel 1998 Military Base Conversion and Rural Development ESRC Application, Centre for Rural Economy, University of Newcastle-upon-Tyne

[9] Albrecht, Kaldor M \& Schméder G 1998 Restructuring The Global Military Sector Volume II: The End of Military Fordism

[10] Kaldor M and G. Schméder (1997) The European Rupture: Defence Sector in Transition Elgar, Cheltenham

[11] Broska 1998 'Conversion in a resource-reuse perspective' COST 10 Network workshop Bled Slovenia July

[12] Ministry of Defence 1998 Strategic Defence Review Cm 3999 TS0 London

[13] Chancellor of the Exchequer 1998 Comprehensive Spending Review Modern Public Services for Britain_Csr Cm 4011

[14] Woodward Rachel 1998 Rural Development and the Restructuring of the Defence Estate: A Preliminary Investigation Research Report, Centre for Rural Economy, University of Newcastle upon Tyne

[15] Bonn International Centre for Conversion 2006

[16] Bonn International Centre for Conversion Conversion Surveys of Global Disarmament, Demilitarization and Demobilization of 1996, 1997, 2002 and 2003

[17] www.bicc.de/publications/brief/brief18/content.php

[18] Myrttinen Henry 2003 Base Conversion in Central and Eastern Europe 1989-2003 Bonn International Center for Conversion Bonn

[19] Batchelor Peter, Cock Jacklyn \& McKenzie Penny 2006 Conversion in South Africa in 1990's: Defense Downsizing and Human Development Challenges BICC Brief 18 Bonn International Center for Conversion and Group for Environmental Monitoring, Johannesburg $61 \mathrm{pp}$

[20] DLO and Defence Estates n.d. Project Prime Portsmouth Regeneration and Investment in the Maritime Estate HM Naval Base Portsmouth

[21] Wildridge Graeme and Marshall Gavin Defence Estates 2005 Interview with Celia Clark Semaphore Tower 21 January 2005

[22] Hussain Amjad Cdre 2004 'Development Plan for Portsmouth Naval Base' 16 June Navy News Portsmouth http://www.navynews.co.uk /articles/2004.0406/000461601.asp

[23] Goodship Peter \& Carpenter Lorraine 2005 Naval Base Property Trust Interviews with Celia Clark The Hard, Portsmouth 21 January 2005, 1 March 2005

[24] Haler Peter 2005 in Barry Jane 'A common touch. It is time for flatowners to assert their newly won rights. Now Britain is only 50 years behind' Lease www.lease-advice.org Evening Standard Homes \& Property 26 January 2005 p.10 London

[25] The News Portsmouth March 172005 p.8 Johnston Newspapers Plc. Portsmouth UK 
[26] Maddox David 2005 "Tories will save ships from axe, says Howard" The News 30 March p.2 Johnston Newspapers Plc. Portsmouth UK

[27] Norwegian Defence Construction Service 1999 Letter to Celia Clark 9 December

[28] DLA Gordon 1997 Managing the changing political environment in urban waterfront redevelopment Urban Studies 1997 p 34; DLA Gordon 1999 'Implementing urban waterfront redevelopment in an historic context: a case study of the Boston Naval Shipyard p.925 Journal of Ocean and Coastal Management 42 (1999)

[29] Woodward Rachel 2004 Military Geographies Blackwell Publishing Oxford p.3 